\title{
Czeslaw Tubilewicz, Taiwan and Post-Communist Europe. Shopping for Allies
}

\section{J. Bruce Jacobs}

\section{(2) OpenEdition}

12 Journals

Édition électronique

URL : http://journals.openedition.org/chinaperspectives/2743

DOI : 10.4000/chinaperspectives. 2743

ISSN : 1996-4617

Éditeur

Centre d'étude français sur la Chine contemporaine

\section{Édition imprimée}

Date de publication : 15 décembre 2007

ISSN : 2070-3449

Référence électronique

J. Bruce Jacobs, «Czeslaw Tubilewicz, Taiwan and Post-Communist Europe. Shopping for Allies », China Perspectives [En ligne], 2007/4 | 2007, mis en ligne le 09 avril 2008, consulté le 23 septembre 2020. URL : http://journals.openedition.org/chinaperspectives/2743 ; DOI : https://doi.org/10.4000/ chinaperspectives. 2743

Ce document a été généré automatiquement le 23 septembre 2020.

(C) All rights reserved 


\section{Czeslaw Tubilewicz, Taiwan and Post-Communist Europe. Shopping for Allies}

\section{J. Bruce Jacobs}

1 This book joins Chen Jie's Foreign Policy of the New Taiwan: Pragmatic Diplomacy in Southeast Asia (Elgar, 2002) as a leading analysis of the foreign relations of democratic Taiwan . Tubilewicz's book analyses Taiwan 's relations with the European nations that had been Communist prior to 1990. Before then, the former dictatorial Kuomintang government had forbade any sort of relations, including trade, with its Communist "enemies," thus providing a special challenge for a newly democratic Taiwan trying to gain "international space."

2 Tubilewicz breaks his analysis into five geographical parts. Taiwan made its first overtures to Central Europe, including Hungary, Czechoslovakia, and Poland . These countries were all anti-Communist, and the aftermath of the Beijing Massacre of 3-4 June 1989 gave Taiwan further opportunities. In addition, Taiwan hoped these countries would assist Taiwan 's entry into Western Europe . President Vaclav Havel of Czechoslovakia initiated "first ladies diplomacy," with Mrs. Havel visiting Taiwan on his behalf. Prague also gave Premier Lien Chan VIP treatment during a 1995 visit. In the Baltic region, Latvia provided Taiwan with an important breakthrough. Even though Latvia recognized the People's Republic, it also established consular relations with Taiwan in early 1992, a dual-recognition that continued until mid-1994, when Latvia had a change of government. Tubilewicz notes that this arrangement was not unique in that Britain had a consulate in Taiwan from 1950 to 1972, the Netherlands had a consulate in Taiwan during 1954-1972, and Taiwan had a consulate in a provincial Nigerian city in 1993.

3 Although Taiwan was late to establish trade and other links with Russia , these links developed reasonably well. While ultimately Russia supported China internationally, Tubilewicz argues that the current status quois to Russia 's advantage, while a “resolved ' Taiwan problem' is not necessarily in actually been reinforced. Russia 's 
interest" (p. 122). He concludes that despite Russian arms sales to China , "Realpolitik seemingly demands that Moscow does not encourage a military resolution of the " Taiwan problem"' (p. 122).

4 Although Taiwan paid little attention to the Balkans, this area receives two chapters because of the establishment of formal diplomatic relations between Macedonia and Taiwan from early 1999 until June 2001, thus giving Taiwan its second "diplomatic ally" in Europe after the Vatican . Finally, Tubilewicz considers the Ukraine and Belarus , two relatively powerful economies in the former Soviet Union .

5 Several structural factors have inhibited Taiwan 's moves in post-Communist Europe since the early 1990s. First, China as a member of the United Nations Security Council has a veto over new memberships and key proposals. Many of the newly independent nations of post-Communist Europe, especially the Baltic and Balkan nations, wanted UN membership and feared a Chinese veto. Chinese vetoes of UN peacekeeping assistance to Macedonia in the wake of the Yugoslav wars also reduced Macedonia 's resolve to maintain relations with Taiwan .

6 Second, the great Latvia and Macedonia breakthroughs were not as great as they seemed. Taiwan- Macedonia diplomatic relations failed to reach ambassadorial level, while the Latvians never established a consulate in Taiwan .

7 Finally, despite the importance of democracy and human rights in Taiwan and in many of the countries of post-Communist Europe, the key factors in Taiwan's relationships with post-Communist Europe were economic. In the early 1990s, most of these countries were experiencing great economic difficulties, while Taiwan had substantial foreign currency reserves and keen businessmen ready to invest overseas in profitable markets.

8 Yet, despite numerous promises of economic assistance, Taiwan repeatedly failed to follow through. Bureaucratic and other obstacles made investment in Central and Eastern Europe problematic. Furthermore, the Taiwan government could not force its businessmen to invest in particular places. Thus, many of the promises of economic assistance remained unfulfilled. In addition, trade with Eastern Europe, though it expanded greatly, remained very small in the context of Taiwan 's overall economic activity. Similarly, while Taiwan trade proved important to some smaller eastern European countries, it was not important to the larger countries. By 2005, trade with the Czech Republic, Hungary, Poland, and Slovakia ranged from US\$230 million to just over US $\$ 500$ million, while trade with the three Baltic nations ranged from US $\$ 50$ million to US\$106 million. Trade with the Balkan states remained small, and Taiwan 's trade with Macedonia barely reached a maximum of US $\$ 4$ million in 2001, a figure that has since declined. In contrast, China 's trade with Macedonia has exceeded US\$10 million since 2001 and reached over US $\$ 35$ million in 2003. Only Russia, which exports raw materials to Taiwan, has reached substantial trade figures with Taiwan of US $\$ 2,712$ million in 2005 . These figures, however, total less than one per cent of Taiwan 's total trade of US\$381,000 million in 2005.

9 As Tubilewicz concludes, Taiwan 's attempts to establish relations with these countries have produced successes as well as failures. Taiwan has several offices in several of these countries, and some of these countries also have offices in Taipei . Trade relationships have been established, and there are many visits between Taiwan and these countries, as well as academic and culture exchanges. These positives have all 
been built de novo, as no relationships existed between Communist Europe and the dictatorships of Chiang Kai-shek and Chiang Ching-kuo.

10 Taiwan and Post-Communist Europe has an excellent bibliography. An added plus is the helpful inclusion of many Chinese characters within the text rather than in a glossary. 